\title{
THE SCOPE OF PROTECTION AND FINANCING OF SOCIAL RISK IN POLAND ON THE EXAMPLE OF THE SOCIAL SECURITY ADMINISTRATION
}

\author{
doi: $\quad 10.2478 /$ czoto-2019-0107 \\ Date of submission of the article to the Editor: $10 / 11 / 2018$ \\ Date of acceptance of the article by the Editor: 28/12/2018
}

Roman Garbiec - orcid id: 0000-0001-9868-6204

Czestochowa University of Technology, Poland, roman.garbiec@wz.pcz.pl

\begin{abstract}
Social risks are an unusual type of risks occurring in insurance. Their specific feature is the implementation of risk in the sphere of social life of a person with special regard to the work environment. Social risks are an element of research in economics and law and in social policy. The author of the paper shows that the structure of the Polish social insurance system is not optimal and requires radical reform. This paper contains, among others, characteristics of the scope of protection of social risks identified in Poland by Social Security Administration and the basis for financing benefits from this system. The summary of the paper presents opinions on improving the financial efficiency of this system.
\end{abstract}

Keywords: social risk, insurance, security system, financial system effectiveness, Social Security Administration.

\section{INTRODUCTION}

In the sphere of social security, the Polish state guarantees its citizens a minimum subsistence in situations where they cannot provide for themselves the means to survive. One way of ensuring the livelihood of citizens should be a properly structured social security system. Its construction and the applied parametric solutions are decided by the legislative and executive bodies of the state. Currently, these bodies are facing new challenges in terms of reducing negative social phenomena, such as a reduction in the number of births and an ageing population. The solutions adopted in 1999 introduced by the reform of the social security system turned out to be inappropriate, and the developing negative demographic processes will result in permanent involvement of the state in reducing the financial deficit of the Social Security Administration. The scale of this shortfall, for the reasons indicated above, will progressively increase and will lead to the insolvency of the institution in the near future. In order to counteract this process, it is necessary to make changes in the social security system. The aim of this article is to present the scope of applied social protection in the Polish social security system, the principles of its financing and to indicate actions allowing for the reduction of the existing financial deficit. According to the author, it is necessary to make non-systemic, systemic and parametric changes in 
order to balance state subsidies to the Social Security Administration. In the research conducted by the author, the analysis of documents and economic analysis of ZUS' receipts and expenditures were used as a research method.

\section{METHODOLOGY OF RESEARCH}

The basic assumption of the study was a thesis that there is a possibility of improving the financial efficiency of the Social Security Administration through the reconstruction of the social insurance system. Such reconstruction should be based on systemic and parametric changes in social insurance supported by possible economic and social changes (so-called non-systemic) in the national economy. In order to diagnose the existing state of affairs, a measure of the financial effectiveness of the system was used as a research tool.

Using the above mentioned measure of financial effectiveness, the study adopted the rule that expenditures are the sum of financial resources accumulated in the system, and the effects are the sum of all benefits paid to eligible persons according to the criteria defined by the system's creator. The financial effectiveness of the social insurance system (as well as of the examined entity, i.e. the Social Security Administration) should be based on an actuarial account, which means it requires the application of the principle that the incurred outlays (premiums) balance, or exceed the incurred effects-paid benefits.

To achieve this equity it is necessary to balance the system incomings and expenditure, i.e. discounted value of all contributions paid into the fund each month throughout the insurance lifecycle (per year) increased by a reserve, if any (or system initial debt) must equal to the discounted value of all benefits currently paid. It can be expressed by the following equation:

$$
\mathrm{Ro}+\frac{1}{(1+\mathrm{r})^{\mathrm{n}}} \sum_{\mathrm{i}=1}^{m} \sum_{j=1}^{n} \mathrm{C}_{\mathrm{ij}}=\frac{1}{(1+\mathrm{r})^{\mathrm{n}+\mathrm{s}}} \sum_{k=1}^{p} \sum_{l=1}^{s} \mathrm{~b}_{\mathrm{kl}}
$$

where:

$R_{0}$ - reserves or initial debt upon system implementation,

$\mathrm{c}_{\mathrm{ij}}$ - value of the contribution paid in by a payer $\mathrm{i}$ in the period $\mathrm{j}$,

$b_{k l}$ - value of the benefit paid to the person $k$ in the period $\mathrm{l}$,

$r$ - rate of return (depending on the system, a rate of return of the investment or a

rate of increase of the payroll budget),

$m$ - number of contribution payers,

$\mathrm{n}$ - number of contribution payment periods,

$p-$ number of beneficiaries receiving benefits,

s - number of benefit collection periods („Safety Thanks to Diversity”, 1997).

The ratio of income (contributions) to expenditure (benefits and administrative costs) in the social insurance system presented in the above formula is an optimal eventuality, however, the actual statement of these variables is presented by socalled financial effectiveness of the social insurance system. The formula for the financial efficiency of the social security system can be defined as follows:

$$
\left\{\begin{array}{l}
\text { for } S k \geq S w+K f(S e) \geq 1 \text { effective (insurance) system } \\
\text { for } S k<S w+K f(S e)<1 \text { ineffective (insurance }+ \text { provision = hybrid) system }
\end{array}\right.
$$


where:

$f(S e)$ - financial efficiency of the social security system,

Sk - social security contributions,

$\mathrm{Sw}$ - benefits paid out of the scheme,

$\mathrm{K}$ - administrative costs (Garbiec, 2013).

A given social security system may be considered financially effective if it reaches the value of a measure equal to unity. Any results below this value will indicate a need for systemic or parametric changes. Systemic changes mean these activities of legislative and executive bodies that change the scope of protection of social risks, or re-organise them. Parametric changes, on the other hand, consist in changes of the rules of collecting contributions or paying social benefits due by virtue of the execution of a given social risk.

\section{RESULTS}

Social security systems that guarantee a minimum subsistence for the citizens of a given country are financed by various techniques. It is the state that defines the catalogue of social risks and the techniques of its financing. Financing techniques include an insurance-based technique (based on the principle of benefits payment only to persons who have been paying premiums), a provision technique based on the principle of benefit payment without paying any premiums, and assistance (care) where benefits are paid to persons who do not pay premiums but meet certain income criteria. In Poland, social risks covered by protection at the Social Security Administration are financed with the use of the insurance-based method. As indicated by the data below, this financing is not sufficient and the scale of shortages is significant, which results in the need for the state to supplement the ZUS deficit. Taking into account unfavorable demographic trends, which cannot be avoided by Poland in the years 2025-2050, this deficit (currently corrected by ad hoc legislative changes) will grow dramatically. The financial efficiency of the social security system before and after the system reform in Poland is presented in the Table 1.

Table 1

Financial efficiency of the social security system before and after the system reform in 1999

\begin{tabular}{|c|l|l|l|l|}
\hline Year & $\begin{array}{c}\text { State } \\
\text { subsidies to } \\
\text { Social } \\
\text { Security } \\
\text { Administration } \\
\text { (ZUS) in } \\
\text { million PLN }\end{array}$ & $\begin{array}{c}\text { State budget } \\
\text { revenues in } \\
\text { million PLN }\end{array}$ & $\begin{array}{c}\text { Share of State } \\
\text { subsidies to Social } \\
\text { Security Administration } \\
\text { (ZUS) in total state } \\
\text { budget revenues (in \%) }\end{array}$ & $\begin{array}{c}\text { Financial } \\
\text { efficiency of } \\
\text { the Social } \\
\text { Security } \\
\text { Administration }\end{array}$ \\
\hline \multicolumn{5}{|c|}{ Before the reform } \\
\hline 1991 & 881.9 & 210881 & 10.56 & 0.8063 \\
\hline 1992 & 4950.8 & 31277 & 13.23 & 0.7790 \\
\hline 1993 & 6605.2 & 45900 & 10.92 & 0.7968 \\
\hline 1994 & 8296.9 & 63124 & 12.58 & 0.7658 \\
\hline 1995 & 6000.0 & 83722 & 7.13 & 0.8549 \\
\hline 1996 & 6031.4 & 99674 & 5.86 & 0.8741 \\
\hline 1997 & 7000.0 & 119771 & 6.70 & 0.8895 \\
\hline 1998 & 8792.8 & 126559 & 6.35 & \\
\hline
\end{tabular}




\begin{tabular}{|l|l|l|l|l|}
\hline \multicolumn{5}{|c|}{ After the reform } \\
\hline 1999 & 9459.0 & 125922 & 23.66 & 0.6884 \\
\hline 2000 & 20082.5 & 135664 & 14.80 & 0.7323 \\
\hline 2001 & 25743.6 & 140527 & 18.31 & 0.6902 \\
\hline 2002 & 30617.1 & 143520 & 21.33 & 0.6875 \\
\hline 2003 & 31935.6 & 152111 & 20.99 & 0.6882 \\
\hline 2004 & 33535.0 & 156281 & 21.45 & 0.7039 \\
\hline 2005 & 32893.60 & 179772 & 18.29 & 0.6821 \\
\hline 2006 & 37904.5 & 197640 & 19.17 & 0.7375 \\
\hline 2007 & 31859.0 & 236368 & 13.47 & 0.6115 \\
\hline 2008 & 52694.8 & 253547 & 20.78 & 0.5712 \\
\hline 2009 & 64948.8 & 274183 & 23.68 & 0.5556 \\
\hline 2010 & 71463.6 & 250303 & 28.55 & 0.6153 \\
\hline 2011 & 64118.3 & 277557 & 23.10 & 0.6973 \\
\hline 2012 & 52928.9 & 287595 & 18.40 & 0.6689 \\
\hline 2013 & 60843.8 & 279151 & 21.79 & 0.6689 \\
\hline 2014 & $60607.7^{1}$ & 283543 & 21.37 & 0.6838 \\
\hline 2015 & $56199.6^{1}$ & 289137 & 19.43 & 0.7182 \\
\hline 2016 & $53269.9^{1}$ & 314684 & 16.92 & 0.7406 \\
\hline 2017 & $40978.7^{1}$ & 350,499 & 11.69 & 0.7840 \\
\hline
\end{tabular}

Source: In-house study based on www.zus.pl and the Statistical Yearbook of the Republic of Poland for the years 1990-2017; https://www.mf.gov.pl/ministerstwo-finansow/activity/public finance/public-budgets/execution-budzet-government/asset_publisher/i1EC/content/estimated data-o-execution-budzet-government-w-2017-r.

1 - This year there was a reduction in subsidies due to changes in the second pension pillar (Pillar II) (taking over a part of the funds by ZUS from the Open Pension Fund (OFE), conversion of the obligatory participation into voluntary participation, etc.).

The necessity to supplement a deficit in the budget of the Social Security Administration by the state budget results from legal acts which stipulate that the state is the guarantor of current payments of ZUS benefits. Unfortunately, budgetary resources are spent on the current consumption of certain social groups and not on investments that will ensure further development to the state. The less funds will be allocated from the state budget for subsidies to the Social Security Administration (ZUS), the more funds will be allocated for pro-development investments. The reform of the social security system in Poland carried out in 1999, instead of improving its financial effectiveness, has significantly worsened it, and the upcoming demographic changes will result in a further decrease in this effectiveness. The growing number of benefit recipients resulting from longer life expectancy and the decreasing number of people paying contributions (covered by social insurance) due to falling number of babies born will result in a systematic increase in state subsidies to the Social Security Administration. A permanent increase of state subsidies to the social security system may lead to a collapse of public finances in the near future. It is therefore necessary to take actions as soon as possible in order to change the principles of the system's functioning. In the next few years, forecasts as to the size of ZUS deficit confirm the current negative trends in this respect, and the least favourable years in terms of demographics (and financial efficiency, as well) will start in a few years' time. The deficit forecast for the coming years is presented in the Table 2. 
Table 2

Forecast of a deficit of the Social Security Administration for 2018-2022

\begin{tabular}{|l|l|l|l|}
\hline \multicolumn{1}{|c|}{ Year } & $\begin{array}{c}\text { Receipts in mln } \\
\text { PLN }\end{array}$ & $\begin{array}{c}\text { Expenditures in mIn } \\
\text { PLN }\end{array}$ & \multicolumn{1}{c|}{$\begin{array}{c}\text { Financial } \\
\text { effectiveness }\end{array}$} \\
\hline \multicolumn{5}{|c|}{ Moderate variant } \\
\hline 2018 & 176135 & 232494 & 0.7575 \\
\hline 2019 & 185543 & 245294 & 0.7564 \\
\hline 2020 & 195971 & 259529 & 0.7551 \\
\hline 2021 & 206564 & 274952 & 0.7512 \\
\hline 2022 & 217704 & 290988 & 0.7481 \\
\hline \multicolumn{5}{|l|}{ Pessimistic variant } \\
\hline 2018 & 169460 & 234558 & 0.7224 \\
\hline 2019 & 175474 & 247450 & 0.7091 \\
\hline 2020 & 181699 & 261306 & 0.6953 \\
\hline 2021 & 187582 & 275832 & 0.6875 \\
\hline 2022 & 193754 & 290330 & 0.6673 \\
\hline \multicolumn{5}{|l|}{ Optimistic variant } \\
\hline 2018 & 181426 & 229871 & 0.7892 \\
\hline 2019 & 192820 & 242285 & 0.7958 \\
\hline 2020 & 205399 & 256206 & 0.8016 \\
\hline 2021 & 218545 & 271489 & 0.8049 \\
\hline 2022 & 232579 & 287641 & 0.8085 \\
\hline
\end{tabular}

Source: In-house study based on http://www.zus.pl/documents/10182/24106/Prognoza FUS_2018_2022.pdf/2cc8d322-f9f2-4bb4-98d2-faef1618a9b9; www.zus.pl

\section{DISCUSSION}

The analysis of social risks applied in social policy is, in most cases, based on their definition and specification of a catalogue of risks. The International Labour Organisation Social Security (Minimum Standards) Convention No. 102 defined the following social risks to fall within the realm of 'social security':

1) The need for medical care.

2) Temporary incapacity for work (sickness cash benefit).

3) Unemployment.

4) Old age.

5) Work accident and occupational disease.

6) The responsibility for the maintenance of children (family benefits).

7) Maternity.

8) Long-term incapacity for work (invalidity).

9) Death of breadwinner (survivor's benefit) (Nickles and Siedl, 2004).

In the opinion of $\mathrm{G}$. Uścińska the basic legal act taken into account in such an analysis is the concept of social risk given in Convention No 102, which links social risks to a specific benefit, namely:

1) Sickness - this risk is complex and inhomogeneous, it is designed to compensate for a loss of earnings as a result of illness and includes healthcare (medical) services and/or sickness cash benefits.

2) Unemployment - a loss of earnings where a protected individual is still fit for work but cannot find a proper job.

3) Old age - provision of cash benefits to anyone reaching the prescribed age (which should not be more than 65). 
4) Work-related accident or injury, work-related disease - a complex risk, defined in a wide and precise manner).

5) Family and parenting support - provision of cash and/or in-kind support for lowincome families raising children.

6) Maternity - cash support and healthcare (medical) services for a protected female

in relation to a loss of earnings during pregnancy, delivery, and in the postpartum period, and to a need for healthcare services in these periods.

7) Disability - inability to perform any physical labor to a degree specified after a disability assessment, if it is total and presumably permanent or persistent and causes a loss of earning.

8) Death of the breadwinner - a loss of support suffered by a widowed person or a child as the result of death of the breadwinner (Uścińska, 2005).

The catalogue of all protected social risks in Poland is comprised in the elements of social protection, which include: social insurance, health insurance, insurance against job loss, benefits for the disabled, social assistance, pro-family benefits, social protection of uniformed services and social protection of farmers.

The subject of this study is the Polish social security system and the risks protected by it, namely: the risk of old age covered by the pension insurance; the risk of longterm inability to work (disability risk) and the risk of death of the breadwinner covered by the disability insurance; the risk of short-term inability to work (sickness risk) and maternity covered by the sickness insurance and the risk of accidents at work and occupational diseases covered by the accident insurance. In accordance with the provisions of Regulation of the European Council No. 883 of 2004 on the coordination of social security systems in the European Union, a rule of autonomous decision of each Member State is applied as to what kind of social risk and how it is protected in it. Therefore, in Poland, according to this rule, these risks are financed with the insurance-based method and serviced by the Social Security Administration (SSA). Acceptance of the existing state of affairs and further passivity in the face of negative processes affecting the financing of the social security system inevitably leads to the collapse of public finances and, as a consequence, the bankruptcy of the Polish state. Undertaking ad hoc measures not supported by a structural reform of the whole system is a short-sighted measure which does not ensure the self-financing of the Polish social security system.

\section{CONCLUSION}

Unavoidable demographic changes and an increase in state subsidies to the social security system require urgent changes, both outside the system, as well as systemic and parametric ones. The changes outside the system include, first of all, an increase in the amount of income earned by insured persons. The low level of salaries results in lower contributions and in the future hunger pension benefits (currently the lowest pension paid by the Social Security Administration amounts to PLN 0.04 per month!). Possible demographic changes (increasing the birth rate) would also improve the system's revenue, unfortunately, the effects of such measures will have to wait at least 20-25 years. Certainly, economic activation of older people (60+) would have a significant impact on improving the financial efficiency of the system, which would not only increase income to the system, but would also ensure an improvement in the living standards of pensioners. 
In the short term, however, systemic changes, such as these shown below, would be much more effective;

- a change in the scope of protected social risks in Social Security Administration by including unemployment risk in the system;

- changing the scope of protected social risks in the Social Security Administration by including a risk of "limitation of a person's physical functioning or mobility" into the system (by means of a care insurance separated from the pension insurance);

- introduction of a uniform system of social insurance without privileges for specific socio-professional groups such as miners, farmers, officers of uniformed services;

- creation of an Individual Social Security Account, acting in accordance with the "combined vessels" principle, in which unused contributions for particular types of disability, sickness and unemployment benefits would increase the pension capital (Garbiec, 2017).

The necessary parametric changes in the scope of social benefits paid include:

- harmonisation of sickness benefits,

- unification of the amount of pension benefits,

- a change in the rules of calculating pension benefits (Garbiec, 2018).

The introduction of all systemic and parametric changes requires another reform of the system. It is difficult to predict whether this implementation will be possible in the upcoming years, but abandoning changes in the social security system at all will result in a collapse of public finances, which will lead, among other things, to a reduction in the amount of social benefits and salaries in the so-called budgetary sphere, a reduction in the standard of living of citizens, a reduction in Poland's GDP, and even to social unrest, such as strikes and riots. Let us hope that this type of situation will not happen.

\section{REFERENCES}

Safety Through Diversity, Reform of the Pension System in Poland, 1997. Office of the Government Plenipotentiary for Social Security Reform, Warsaw.

Garbiec, R., 2017. Construction of a Sustainable Social Security System in Poland in Managerial Trends in the Development of Enterprises in Globalization Era. Slovak University of Agriculture in Nitra, Nitra, 572.

Garbiec, R., 2013. Financial Effectiveness of Public Social Security System in Poland after the Reform of 1999. Editorial House of the Czestochowa University of Technology, Czestochowa.

Garbiec, R., 2018. Financing and Assessment of Pension benefits in the Public Social Security System in Poland. Conference BUSINESS COST MANAGEMENT. HISTORY AND PRESENCE, Czestochowa.

https://www.mf.gov.pl/ministerstwo-finansow/dzialalnosc/finanse-publiczne/budzetpanstwa/wykonanie-budzetu-panstwa/szacunkowe-wykonanie-budzetu/-/asset_ publisher/i1EC/content/szacunkowe-dane-o-wykonaniu-budzetu-panstwa-w-2017r.

https://www.zus.pl

https://www.zus.pl/documents/10182/24106/Prognoza_FUS_2018_2022.pdf/2cc8d32 2-f9f2-4bb4-98d2-faef1618a9b9; www.zus.pl

Nickles, J., Siedl, H., 2004. Co-ordination of Social Security in the Council of Europe. Short Guide, Council of Europe Publishing, Strasbourg. 
https://books.google.pl/books?id=5pPT-5WSxGsC\&pg=PA15\&lpg=PA15\&dq=the +concept+of+social+risk+given+in+Convention+No+102+of+the+International+lab our+Organisation+(ILO)\&source=bl\&ots=DSdZKWau0\&sig=xQGh5iRoC6vsR2cnp o3V7Vb_I_M\&hl=pl\&sa=X\&ved=2ahUKEwiAo_4h9zfAhXsklsKHbr5ASAQ6AEwBn oECAgQAQ\#v=onepage\&q=the\%20concept\%20of\%20social\%20risk\%20given\%2 Oin\%20Convention\%20No\%20102\%20of\%20the\%20International\%20labour\%200 rganisation\%20(ILO)\&f=true

Statistical Yearbooks of the Republic of Poland, years 1990-2017.

Uścińska, G., 2005. Social Protection Benefits in International and Polish Regulations. Institute for Labour and Social Affairs, Warsaw. 